\title{
Reproductive Health of Yellow Perch, Perca flavescens, in Chesapeake Bay Tributaries
}

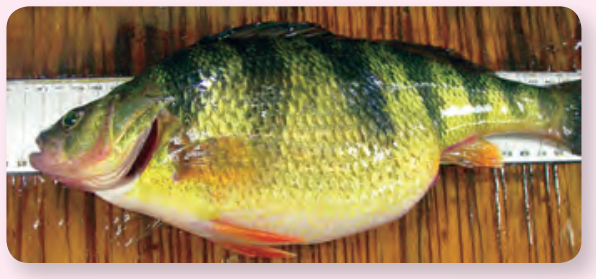

\section{Introduction}

Vellow perch live in creeks, rivers,

ponds, lakes, and estuaries across the central and eastern United States and Canada. In Chesapeake Bay, they tolerate salinities up to one-third that of seawater. The adults reside in the brackish waters of the bay's tributaries and migrate upstream to spawn. Yellow perch are eagerly sought by recreational fishermen for their excellent taste and, because their late winter spawning runs are the earliest of the year, they are regarded as a harbinger of spring. Yellow perch also support a small but valuable, tightly regulated commercial fishery in the part of Chesapeake Bay that lies in Maryland.

\section{Background}

In the early 20th century, Chesapeake Bay supported a major commercial yellow perch fishery. This catch declined drastically and reached a low in the late 1970s. In the early 1980s, the Maryland Department of Natural Resources (DNR) reported a decline in recreational fishing for yellow perch in rivers in the Baltimore-WashingtonAnnapolis area that had long been closed to commercial fishing. After having been closed to recreational fishing for yellow perch for 20 years, these rivers were reopened in 2009. The DNR noted the decline in egg-hatching success from more than 80 percent during the period from the 1920 s to 1960 to less than 10 percent during 2001-05, and concluded that banning fishing would not overcome the poor hatch rate. These Western Shore yellow perch fisheries appeared to be supported by occasional natural stocking from strong upper bay year-classes.

In the tributaries to Chesapeake Bay, yellow perch typically spawn in early March. Females extrude long, accordion-like egg chains that are fertilized by males. These

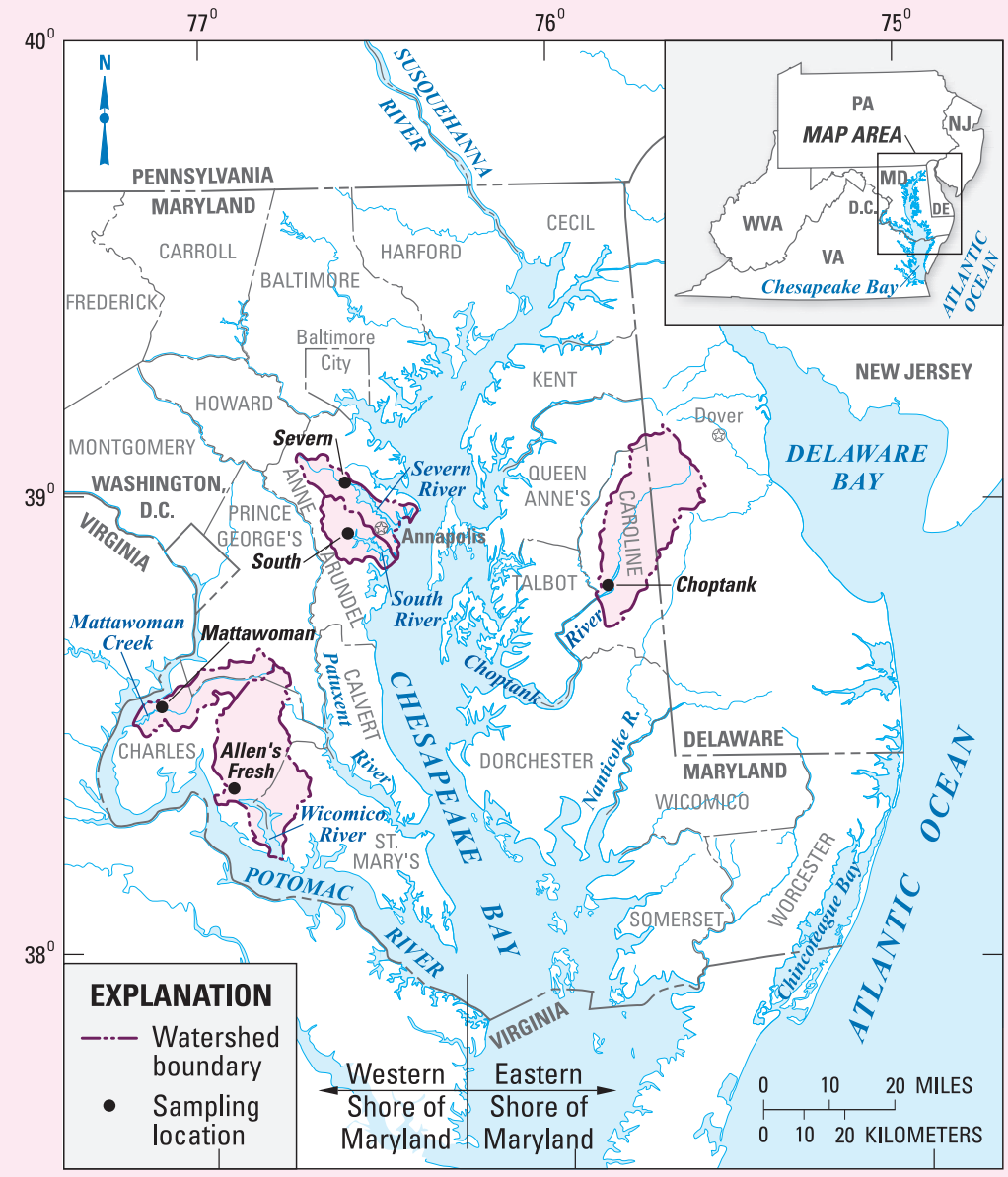

Figure 1. Watersheds of five Chesapeake Bay tributaries and sampling locations, 2007-09.

chains can be easily counted by volunteers walking streambanks or in kayaks. Although the egg mass counts are not consistently determined for all tributaries, they are useful for comparing spawns among rivers. The Maryland DNR conducts larval surveys in some bay tributaries and calculates the percentage of samples that contain yellow perch larvae. This index is an indication of how well eggs and early larvae have survived.

\section{Goals of the Study}

A study was conducted by the U.S. Geological Survey (USGS) in cooperation with the U.S. Fish and Wildlife Service (USFWS) and the Maryland DNR to compare the reproductive health of yellow perch from historically important spawning areas with the goal of improving understanding of the reasons for the observed decrease in reproduction. The study area included five Chesapeake Bay tributaries (fig. 1) whose basins are characterized by varying degrees of urbanization as indicated by the percentage of impervious surface (roads, roofs, parking lots, etc.); these are the Choptank River (2 percent), Allen's Fresh (5 percent), Mattawoman Creek (10 percent), Severn River (21 percent), and South River (25 percent). Several measures of reproductive success in the two tributaries with highly suburbanized watersheds and very low spawning success (the Severn and South Rivers) were compared with those in Mattawoman Creek (in a watershed with extensive forest cover that is undergoing rapid suburbanization), the Choptank River (in a largely agricultural 
watershed), and Allen's Fresh (in a largely forested watershed). This fact sheet summarizes the results of the study.

\section{Field and Laboratory Work}

During each of the 2007, 2008, and 2009 spawning seasons, about 10 male and 10 female yellow perch were collected from each of these rivers (fig. 1). To compare the reproductive status of the spawning fish, the USGS and its partners (1) examined the ovaries and testes microscopically, (2) made sperm counts, (3) measured sperm motility (movement) and other indicators of sperm quality, and (4) measured plasma concentrations of vitellogenin (a protein involved in the production of egg yolk) and reproductive hormones.

\section{Key Findings}

In females, two types of egg abnormalities were observed: thin and irregular zona pellucida (egg envelope) and abnormal yolks (fig. 2). The percentage of egg envelope abnormalities was highest in perch from the South (2007) and Severn (2008, 2009) Rivers. In all 3 years, the percentage of yolk abnormalities was significantly higher in the Severn and South River perch than in those from the three other locations. In all years, none of the Severn River females had eggs that were fully developed at the time of collection.

In males, the major microscopic abnormality was an increase in the number and size of Leydig cells, which secrete the hormone testosterone. This abnormality was observed in perch from the Severn River and, less commonly, in those from Mattawoman Creek. The ranking of the rivers with respect to sperm counts was not consistent from year to year. Sperm motility was significantly higher in the Choptank River perch than in those from Mattawoman Creek (in 2008) and those from both Mattawoman Creek and the Severn River (in 2009).

\section{Conclusions}

Abnormalities in yellow perch ovaries and testes collected from five tributaries to Chesapeake Bay at spawning time were documented over three seasons. The abnormalities were most frequent and severe in perch from the South and Severn Rivers, the two tributaries with the most highly suburbanized watersheds. The detection of these abnormalities helps to explain the biological causes behind the poor survival of yellow perch eggs and larvae in these rivers. Published studies indicate that the abnormalities may result from exposure to environmental contaminants. Follow-up studies are needed to discover which contaminants may be involved, how such contaminants enter and move through the rivers, and how they affect the fish.

\section{The Research Team}

Partners included the USGS National

Fish Health Research Laboratory, the USFWS Chesapeake Bay Field Office and Maryland Fisheries Resource Office, USGS National Wetland Research Center, and the Maryland DNR. Funding was provided by Mirant Corporation (now a part of NRG Energy, Inc.); the USFWS; and the USGS Priority Ecosystems Science-Chesapeake Bay, Fisheries, and Toxic Substances Hydrology Programs. The authors appreciate the assistance with egg strand counts provided by the Coastal Conservation Association Maryland and Arlington Echo.

\section{For Additional Information}

Blazer, V.S., Pinkney, A.E., Jenkins, J.A., Iwanowicz, L.R., Minkkinen, Steven, Draugelis-Dale, R.O., and Uphoff, J.H., 2013, Reproductive health of yellow perch Perca flavescens in selected tributaries of the Chesapeake Bay:

Science of the Total Environment, v. 447, p. 198-209 (available online at http:// www.sciencedirect.com/science/article/pii/ S0048969712016452).

Vicki S. Blazer

vblazer@usgs.gov

A.E. (Fred) Pinkney

fred_pinkney@fws.gov

James H. Uphoff

juphoff@dnr.state.md.us

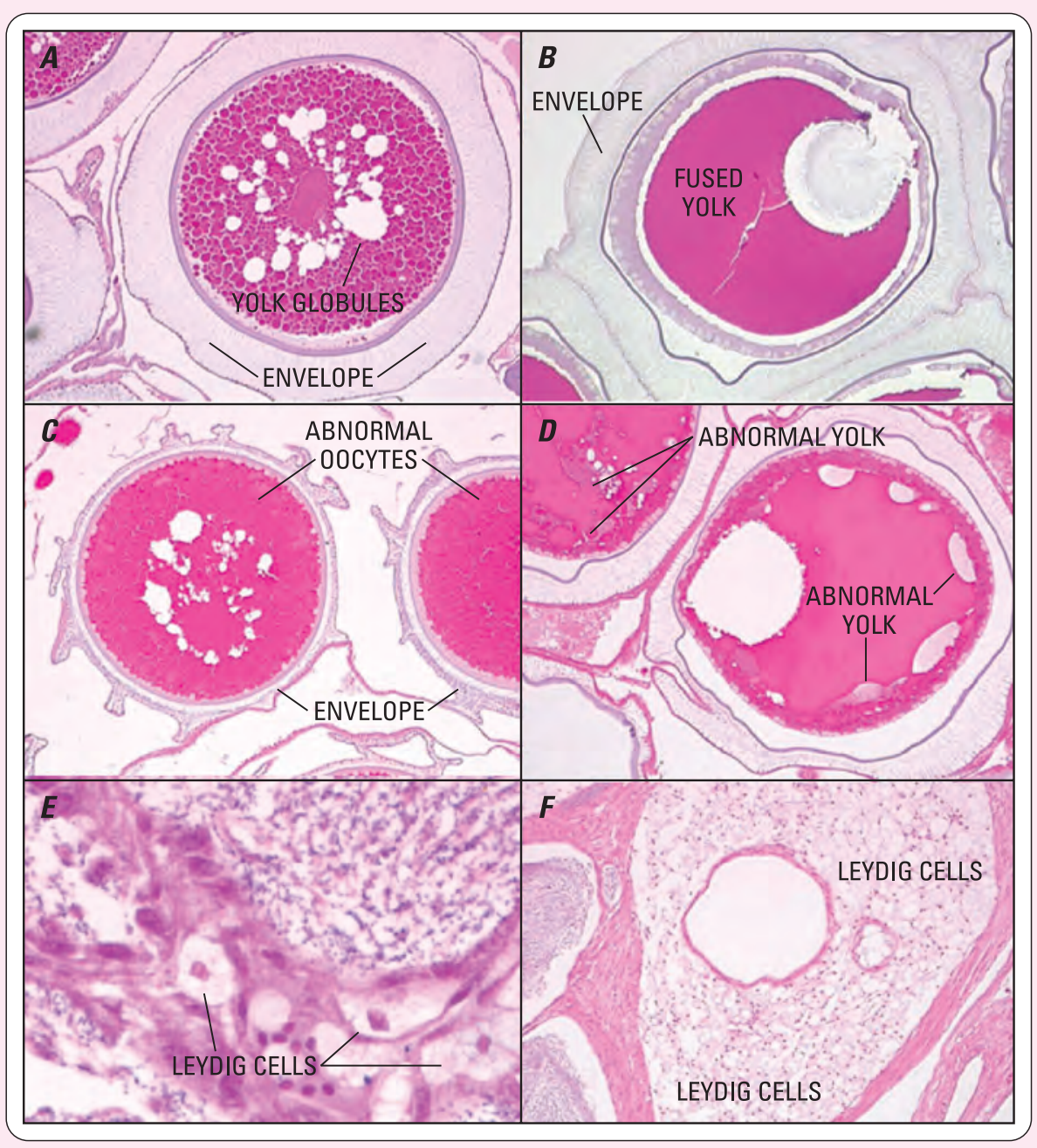

Figure 2. Microscopic appearance of yellow perch gonads. $(A)$ normal stage 3 oocyte with yolk globules and zona pellucida or envelope; $(B)$ normal stage 4 oocyte with fused yolk and egg envelope; $(C)$ abnormal oocytes from a South River perch with thin, irregular egg envelope; (D) oocytes from a Severn River perch with abnormal yolk; (E) englarged Leydig cells in the testes of a Severn River perch; and (F) abnormal accumulation of Leydig cells in testes of a Severn River perch. 